\title{
TV Publik dan Lokalitas Budaya: \\ Urgensinya di Tengah Dominasi TV Swasta Jakarta
}

\author{
Puji Rianto \\ Direktur Pusat Kajian Media dan Budaya Populer (PKMBP) \\ Intania Poerwaningtias \\ Peneliti pada Pusat Kajian Media dan Budaya Populer (PKMBP)
}

\begin{abstract}
This article discusses about public service broadcasting and the urgency of culture program, especially the local culture program. This discussion based on the argument that broadcasting in Indonesia is dominated by private television that considered rating as the principal goal. In the other hand, local culture programs are ignored as the result of sentralized broadcasting system. In fact, local culture program is very required. It is showed by the popularity of culture program "Pangkur Jenggleng" that shows on TVRI Jogja. For public service broadcasting, culture program is one of their duty and mission that must be carried on.
\end{abstract}

Keyword: public service broadcasting, private domination, local culture

\begin{abstract}
Abstrak
Artikel ini membahas lembaga penyiaran publik dan urgensi program budaya, terutama yang bermuatan budaya lokal. Bahasan ini didasarkan pada argumen bahwa penyiaran di Indonesia didominasi oleh stasiun televisi swasta yang menganggap rating adalah segalanya. Di sisi lain, program budaya lokal menjadi diabaikan, sebagai hasil dari sistem penyiaran yang sentralistik. Pada faktanya, program budaya lokal sangatlah penting. Ini ditunjukkan dengan popularitas program budaya "Pangkur Jenggleng" yang ditayangkan oleh TVRI Jogja. Bagi lembaga penyiaran publik, program budaya adalah salah satu tugas dan misi yang harus dipenuhi.
\end{abstract}

Kata Kunci: lembaga penyiaran publik, dominasi swasta, budaya lokal

\section{Pendahuluan}

Reformasi 1998 telah mengubah sedemikian rupa sistem ekonomi politik di Indonesia, yang terimbas satu di antaranya adalah sistem penyiaran. Jika pada masa Orde Baru sistem penyiaran diorientasikan untuk melayani negara (baca penguasa), maka setelah Orde Baru tumbang menjadi jauh lebih demokratis.
Indikasinya, baik media cetak maupun elektronik tidak lagi dikenakan pembredelan, dan pihak manapun dilarang menghalangi wartawan menggali informasi. Media benar-benar berorientasi untuk melayani publik dan juga pasar. Namun dominasi televisi swastaterutama televisi swasta Jakarta yang siaran nasional menunjukkan bahwa 
kondisi pertelevisian Indonesia tengah bergerak dari otoritarianisme negara menuju otoriarianisme pasar. Saat ini, ada 11 stasiun televisi siaran nasional, yakni TVRI, RCTI, SCTV, Indosiar, MNC TV, Global TV, Trans TV, Trans 7, ANTEVE, TVOne, dan Metro TV. Di antara kesebelas lembaga siaran tersebut, hanya TVRI yang merupakan televisi publik. Selebihnya, televisi swasta komersial yang sangat sentralistik karena dikuasai oleh beberapa pemilik saja.

Terlalu kuatnya dominasi televisi swasta dalam dunia penyiaran tentu akan mengundang masalah. Pertama, demi mengejar iklan dan keuntungan perusahaan, televisi-televisi swasta itu akan jauh lebih mementingkan rating dibandingkan dengan membuat program acara yang bagus. Akibatnya, tayangan televisi banyak dipenuhi oleh "tayangantayangan sampah" yang hanya menekankan nilai hiburan dibandingkan edukasi. Kedua, tayangan berita dan informasi yang penting dalam mendorong demokrasi akan teracuni oleh motif-motif mengejar rating dan keuntungan. Market-driven journalism (lihat McManus, 1994) akan mengalahkan public-driven journalism sehingga dunia pemberitaan akan dipenuhi berita-berita politik yang penuh skandal, sensasional, dan dangkal. Ketiga, tergerusnya demokrasi lokal. Berita dan informasi adalah prasyarat penting demokrasi. Dominasi televisi Jakarta di daerah membuat publik tidak mendapatkan informasi yang relevan. Bahkan, dalam kasus tertentu, kandidat Gubernur di suatu daerah harus beriklan di televisi Jakarta, begitu pula debat kandidatnya. Hal ini membuat masyarakat di daerah lain harus mendapati informasi yang tidak relevan dengan kehidupan politiknya sehari-hari. Sementara, televisi swasta lokal tidak mampu berbuat banyak karena tersedotnya seluruh sumber daya di daerah oleh televisi-televisi swasta yang siaran nasional.

Dalam situasi semacam ini, keberadaan lembaga penyiaran publik seperti TVRI-terlepas dari persoalan yang melilitnya-sangat dibutuhkan karena beragam alasan pula. Pertama, visi lembaga penyiaran publik sangat berbeda dibandingkan dengan televisi swasta. Eksistensi lembaga penyiaran publik adalah menciptakan program yang mempunyai nilai edukasi dan budaya yang tinggi, sedangkan televisi swasta demi rating dan keuntungan. Kedua, lembaga penyiaran publik seyogianya tidak bergantung pada iklan karena dana disediakan oleh negara (atau bisa juga license fee) sehingga lembaga penyiaran publik lebih bisa diandalkan sebagai sumber informasi. Ketiga, dalam konteks Indonesia, lembaga penyiaran publik seyogianya menjadi penyeimbang lembaga penyiaran swasta yang sangat komersial. Dengan demikian, budaya populer yang berkembang tidak semata budaya pasar, tapi juga budaya yang mempunyai "nilai pencerahan". 
Berangkat dari beragam argumen di atas, tulisan ini ingin menyoroti bagaimana program-program budaya lokal diminati oleh masyarakat. Tulisan ini akan mengambil contoh kasus acara Pangkur Jenggleng Ayom Ayem yang tayang di TVRI Jogja (selanjutnya disingkat menjadi Pangkur Jenggleng). Sebagai lembaga penyiaran publik, menjaga identitas kebudayaan adalah salah satu tugas utama TVRI, dan Pangkur Jenggleng kemudian menjadi salah satu program kebudayaan yang dimaksud. Program ini diangkat sebagai suatu kajian karena setidaknya dua alasan. Pertama, hasil survei menyatakan bahwa Pangkur Jenggleng merupakan tayangan budaya yang paling populer di Yogyakarta, bahkan mampu menembus dominasi televisi - televisi Jakarta yang sangat profit oriented. Ini menunjukkan kuatnya kebutuhan masyarakat akan program budaya yang bersifat sangat lokal. Kedua, dengan menunjukkan betapa program kebudayaan seperti Pangkur Jenggleng diminati khalayak, tulisan ini ingin menunjukkan bahwa dominasi siaran televisi Jakarta di seluruh Indonesia, bukan saja keliru jika dilihat dari aspek hukum, tapi juga menegasikan kebutuhan masyarakat di tingkat lokal. Kebudayaan lokal hanya mungkin dilayani oleh siaran televisi lokal, dan lebih-lebih lembaga penyiaran publik.

\section{Mendefinisikan Lembaga Penyiaran} Publik

Gazali dan Manayang (Gazali, 2002) mengemukakan bahwa lembaga penyiaran publik adalah lembaga penyiaran yang mempunyai visi untuk memperbaiki kualitas kehidupan publik, kualitas kehidupan suatu bangsa, dan juga kualitas hubungan antarbangsa pada umumnya. Selain itu, lembaga penyiaran publik mempunyai misi untuk menjadi forum diskusi, artikulasi, dan pelayanan kebutuhan publik. Menurut Gazali dan Manayang, lembaga penyiaran publik memberikan pengakuan secara signifikan terhadap peran supervisi dan evaluasi oleh publik dalam posisinya sebagai khalayak dan partisipan yang aktif, karena itu lembaga penyiaran publik bukanlah lembaga penyiaran pemerintah serta bukan pula lembaga penyiaran yang semata-mata mendasarkan dirinya pada hukum-hukum pasar.

Acuan lembaga penyiaran publik juga bisa disimak dalam undang-undang penyiaran. Pasal 14 ayat (1) undangundang tersebut menyatakan bahwa lembaga penyiaran publik sebagai lembaga penyiaran yang berbentuk badan hukum yang didirikan oleh negara, bersifat independen, netral, tidak komersial, dan berfungsi memberikan layanan untuk kepentingan masyarakat.

Secara khusus, Pasal 4 PP No. 13 Tahun 2005, mengenai tugas TVRI adalah sebagai berikut. 
TVRI mempunyai tugas memberikan pelayanan informasi, pendidikan, hiburan yang sehat, kontrol dan perekat sosial, serta melestarikan budaya bangsa untuk kepentingan seluruh lapisan masyarakat melalui penyelenggaraan penyiaran televisi yang menjangkau seluruh wilayah Negara Kesatuan Republik Indonesia.

Sasa Djuarsa Sendjaja (2006: 498500) mengemukakan empat alasan mengenai pentingnya lembaga penyiaran publik dalam sistem demokrasi. Pertama, dalam konteks kehidupan demokrasi dan penguatan masyarakat sipil, publik berhak mendapatkan siaran yang lebih mencerdaskan, lebih mengisi kepala dengan sesuatu yang lebih bermakna dibandingkan sekadar menjual kepala kepada pemasang iklan melalui logika rating. Kedua, warga berhak memperoleh siaran yang mencerdaskan tanpa adanya batasan geografis, lebih-lebih sosio-politis. Lembaga penyiaran swasta akan selalu berpikir dalam kerangka besaran jumlah penduduk dan potensi ekonomi untuk membuka jaringannya sehingga daerahdaerah yang miskin dan secara ekonomi tidak menguntungkan tidak akan mendapatkan layanan siaran swasta. Oleh karena itu, beberapa pihak mengatakan bahwa perbedaan lembaga penyiaran komunitas dan lembaga penyiaran publik terletak pada banyaknya komunitas yang dilayani (Gazali, 2002; lihat juga Higgins, 2008). Lembaga penyiaran komunitas melayani hanya satu komunitas, sedangkan lembaga penyiaran publik harus melayani banyak komunitas. Oleh karena itu, daya jangkau menjadi sangat penting dalam lembaga penyiaran publik karena jangkauan akan sangat menentukan banyaknya komunitas yang mampu dilayani.

Di titik ini, lembaga penyiaran publik tidak berkait erat dengan pasar, dan tidak berkait dengan rating. Sejauh komunitas itu eksis dalam suatu wilayah layanan, maka komunitas itu harus dilayani berapapun banyaknya. Ketiga, penyiaran publik merupakan entitas penyiaran yang memiliki concern lebih terhadap identitas dan kultur nasional. Keberadaan lembaga penyiaran publik penting dalam rangka menjaga identitas dan kultur nasional yang bersifat dinamis. Keempat, demokrasi media niscaya memerlukan lembaga penyiaran yang bersifat independen, baik dilihat dari kepentingan negara maupun komersial. Lembaga penyiaran yang dikontrol negara akan cenderung menjadi ideological state aparatus, sedangkan lembaga penyiaran yang dikontrol swasta akan mengakibatkan penggunaan logic of accumulation and exclusion sebagai penentu apa dan bagaimana sesuatu ditayangkan.

\section{Urgensi Program Budaya}

Lukas Ispandriarno, dalam kesaksian di Mahkamah Konstitusi, ${ }^{1}$

\footnotetext{
${ }^{1}$ Risalah Sidang Perkara Nomor 78/PUU-IX/2011 Perihal Pengujian Undang-Undang Nomor 32
} 
mengemukakan bahwa kemajemukan budaya bangsa tidak mendapatkan tempat sama sekali dalam layar televisi swasta. Sebaliknya, yang muncul justru sajian infotainment yang dangkal, tidak mengembangkan nalar, tidak menumbuhkan cita rasa yang baik, jauh dari suasana reflektif, dan sebagainya. Hal yang kurang lebih sama dikemukakan oleh Hanif Suranto dari Lembaga Studi Pers dan Pembangunan (LSPP). ${ }^{2}$ Menurutnya, selain bahwa media-media lokal sangat bias Jakarta, konsentrasi kepemilikan pada akhirnya berimbas pada homogenisasi isi, dan pada upaya penunggalan opini publik.

Dominannya neoliberalisme dalam penyelenggaraan penyiaran di Indonesia akan berimplikasi serius bagi masa depan demokrasi dan kebudayaan di Indonesia. Sebagaimana dikemukakan Kellner (2010: 1), budaya media hadir di mana citra, suara, dan lensa membantu menghasilkan rajutan kehidupan sehari-hari, mendominasi waktu luang, membentuk pandangan-pandangan politik dan sikap sosial, dan memberikan bahan yang digunakan orang untuk membangun identitas sosial. Di sini, persoalan krusial muncul ketika media-dalam hal ini televisi-didominasi pasar. Maka, cara pandang terhadap realitas, cara pandang

Tahun 2002 tentang Penyiaran Pasal 18 ayat (1) dan Pasal 34 ayat (4) terhadap Undang-Undang Dasar Negara Republik Indonesia tahun 1945, Rabu 15 Februari 2012.

${ }^{2}$ Risalah Sidang, ibid. demokrasi, kebudayaan, dan seterusnya akan didominasi oleh cara pandang pasar.

Dilihat dari sistem politik demokrasi, kuatnya dominasi pasar ini jelas tidak akan menguntungkan. Dalam Rich Media Poor Democracy, Chesney mengemukakan bahwa hiperkomersialisasi dan oligopoli dalam sistem media telah mengancam demokrasi dan opini publik. Douglas Kellner juga menyampaikan keberatan-keberatan yang sama menyangkut kuatnya kapitalisasi penyiran dan implikasinya bagi demokrasi. Sebagaimana dikemukakan Kellner (Ibrahim, 2011: 7), fondasi dari imperatif kapitalis dalam 'sistem penyiaran' komersial sebagai antitesis bagi demokrasi itu sendiri. Ini disebabkan oleh kurangnya tanggung jawab korporat, akses gelombang udara yang terbatas, dan sempitnya perspektif politik yang ditampilkan.

Tidak bisa dimungkiri, lembaga penyiaran swasta bertugas memaksimalkan keuntungan. Oleh karenanya, prinsip ekonomi akan menjadi pegangan utama. Biaya produksi akan ditekan semaksimal mungkin demi mendapatkan selisih keuntungan yang semakin besar. Maraknya infotainment tak lepas dari prinsip ekonomi ini. Dalam bidang jurnalis, akan muncul apa yang disebut sebagai market-driven journalism (McManus, 1994). Dalam market-driven journalism, liputan lebih menyentuh kebutuhan konsumen dibandingkan dengan warga negara. Biaya liputan akan 
ditekan sedemikian rupa. Investasi untuk sumber daya wartawan juga berkurang. Akibatnya, berita yang dihasilkan dangkal dan kurang bermakna bagi sistem politik demokrasi. Ini karena salah satu syarat penting demokrasi adalah masyarakat yang well-informed (McNair, 2003), tapi prasyarat semacam itu tidak mungkin dipenuhi oleh liputan media yang dangkal dan bias. Akhirnya, situasi yang akan kita hadapi mirip seperti yang pernah disitir McChesney (2000), kita memang mempunyai banyak media, tapi demokrasi kita tetaplah miskin.

Di sisi lain, lembaga penyiaran swasta hidup dari iklan. Ini berarti bahwa semakin banyak lembaga penyiaran swasta akan semakin banyak iklan menerpa masyarakat. Di bidang sosial budaya, ini akan memunculkan suatu masyarakat yang menempatkan konsumsi pada derajat paling tinggi. Akibat lebih lanjut adalah pemujaan atas benda. Eksistensi individu akan lebih ditentukan oleh benda atau barang-barang material yang mereka konsumsi dibandingkan dengan sumbangan mereka terhadap peradaban. Korupsi akan semakin merajalela karena dorongan terusmenerus untuk mengonsumsi. Budaya kita pada akhirnya akan didominasi oleh budaya pasar di mana nilai uang dan transaksi menjadi dasar utama dari relasirelasi sosial yang lebih luas. Bagaimanapun, media penting karena ia mampu "menyosialisasikan produkproduk kapitalis, membangun citra atasnya sehingga konsumsi produk berdasarkan nilai guna menjadi konsumsi produk berdasarkan nilai tanda menjadi mungkin dan berlangsung masif.

Di manapun, kapanpun, dan dalam situasi bagaimanapun iklan senantiasa menghipnotis manusia, mensubversi dan mengaburkan batas-batas antara kebutuhan dan keinginan. Itu hanya mungkin melalui media, terutama melalui periklanan komersial. Di sinilah, program budaya-yang tidak semata komersialmenjadi begitu urgent. Sebagaimana dikemukakan Gazali (2002: 34), salah satu pembeda utama lembaga penyiaran publik dan swasta adalah pada program budaya. Lembaga penyiaran publik berkewajiban membuat program-program mengenai budaya dan tradisi serta kearifan di dalamnya yang mungkin telah tertinggal sedemikian rupa karena kita terlanda sedemikian rupa oleh budaya populer, budaya kontemporer, budaya langsung jadi yang lama-lama membuat kita terbiasa, dan mulai tidak merasa ada sesuatu yang kosong di batin kita karena kehilangan kearifan dan budaya kita sendiri.

\section{Televisi Publik dan Tayangan Budaya Lokal}

Undang-undang Penyiaran telah menunjuk TVRI sebagai lembaga penyiaran publik televisi. Sebagai sebuah lembaga penyiaran publik, TVRI berkewajiban untuk melayani kebutuhan 
publik. Lembaga penyiaran publik ini harus bisa melayani kebutuhan komunitas yang ada di wilayah siarannya, termasuk komunitas yang minoritas. Pelayanan lembaga penyiaran publik tak boleh tergantung pada ada tidaknya keuntungan yang akan didapat dari iklan dan sponsor. Lembaga penyiaran publik benar-benar tak boleh diintervensi oleh kekuatan negara maupun kekuatan pasar.

Salah satu tayangan yang harus disediakan oleh televisi publik adalah tayangan budaya. Meski tak populer dan tak bisa mendatangkan keuntungan, televisi publik tetap harus memproduksi siaran budaya. Bagaimanapun, tayangan budaya mesti mendapat tempat di dalam televisi. Di tengah tayangan televisi yang hanya mementingkan popularitas dan kemungkinan untuk meraup untung dari iklan-yang notabene menyuguhkan budaya konsumtif-tayangan budaya menjadi kebutuhan yang penting sebagai rujukan bagi publik untuk bisa mengembangkan nalar, menumbuhkan cita rasa yang baik, dan merefleksikan kehidupan sehari-hari.

Tayangan budaya, terutama budaya lokal sangat dibutuhkan oleh publik sebagai bentuk pelestarian budaya dan sumber edukasi. Jika televisi Jakarta bersiaran nasional tak mau membuat program budaya karena tak mendatangkan keuntungan, maka televisi publik menjadi solusi untuk menghadirkan tayangan budaya di tengah masyarakat. Ketika televisi Jakarta tak bisa menyajikan tayangan budaya lokal karena bersiaran nasional, maka televisi publik lokal, baik TVRI daerah maupun lembaga penyiaran publik lokal televisi lainnya harus mampu memproduksi tayangan tersebut karena sesuai dengan konteks lokal di mana lembaga penyiaran publik tersebut berada. Salah satu contoh tayangan budaya lokal yang diproduksi dengan baik adalah acara Pangkur Jenggleng yang diproduksi dan ditayangkan oleh TVRI Jogja.

\section{Pangkur Jenggleng: Tayangan Budaya Lokal yang Populer}

Pangkur Jenggleng adalah acara lokal yang paling diminati warga Yogyakarta dan sekitarnya. Dalam penelitian khalayak yang dilakukan Pustlitbang LPP TVRI dan Inspect (Rianto, dkk, 2013) menemukan bahwa acara ini menjadi salah satu acara televisi lokal yang mampu bersaing dengan televisi Jakarta yang bersiaran nasional. Survei tersebut menanyakan kepada responden tentang tayangan televisi apa yang mereka konsumsi pada pagi, siang, sore, dan malam hari dalam dua hari terakhir (lihat Grafik 1).

Pangkur Jenggleng muncul sebagai program televisi lokal yang mampu bersaing di tingkat nasional. Pangkur Jenggleng memiliki persentase yang mencapai 8,05\%. Grafik 1 menunjukkan program televisi yang ditonton oleh responden pada pagi hingga 
malam hari, namun hanya yang memiliki persentase lebih dari $2 \%$ saja. Dengan demikian, hanya acara yang populer saja yang terlihat di sana.

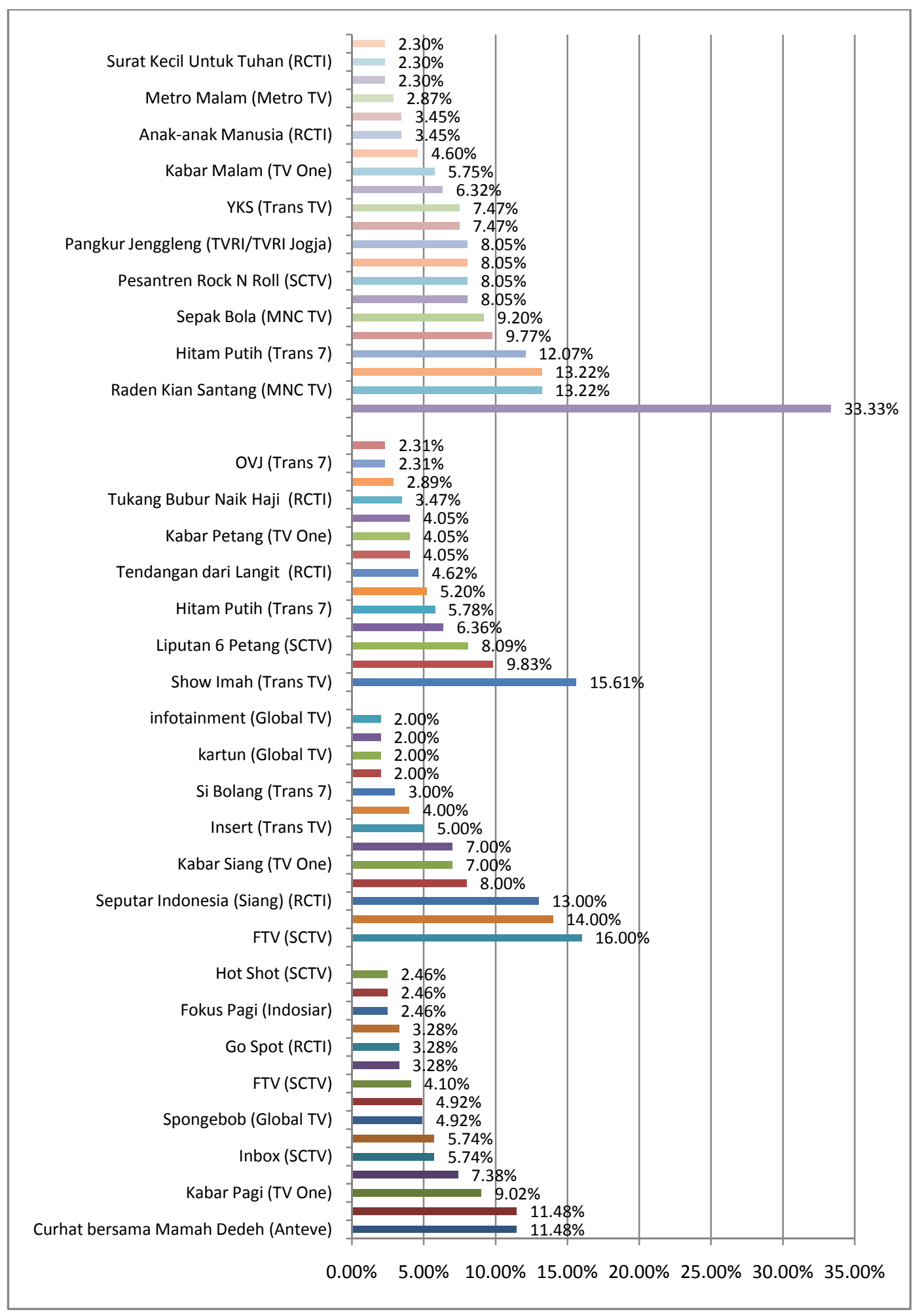

Grafik 1. Program Acara Televisi yang Ditonton di Waktu-Waktu Tertentu 
Dari program-program yang ditonton di waktu-waktu tersebut, hanya Pangkur Jenggleng yang merupakan program budaya. Program yang paling banyak ditonton responden adalah sinetron Tukang Bubur Naik Haji. Program lainnya yang disebut oleh responden adalah program berita, talkshow, sinetron, dan infotainment. Hasil ini secara tidak langsung mengatakan bahwa televisi Jakarta yang bersiaran nasional tidak bisa menciptakan tayangan budaya yang diminati oleh khalayak di tingkat lokal.

Setidaknya ada dua alasan mengapa televisi Jakarta yang bersiaran nasional tidak bisa menciptakan program budaya yang diminati oleh khalayak. Pertama, stasiun-stasiun televisi tersebut tidak mempunyai tempat untuk tayangantayangan budaya. Tayangan budaya memang tak pernah mendapat rating yang sangat tinggi secara nasional. Tentu saja mereka tidak mau membuat tayangan budaya karena alasan tersebut. Bukan hal yang mengherankan lagi jika selama ini televisi-televisi tersebut mendasarkan pembuatan programnya pada rating. Selama ini, rating tertinggi banyak dikuasai oleh tayangan dengan genre sinetron, reality show, dan komedi.

Kedua, televisi Jakarta yang bersiaran nasional tidak mempunyai tempat untuk tayangan-tayangan yang bersifat lokal. Stasiun televisi tersebut tidak mampu merumuskan tayangan budaya yang bisa diterima oleh semua penontonnya. Bagaimanapun, tayangan budaya semacam Pangkur Jenggleng hanya bisa dibuat dengan konteks lokal. Sementara, stasiun-stasiun televisi tersebut memiliki penonton yang berasal dari berbagai wilayah di Indonesia. Tayangan kebudayaan yang dirumuskan oleh stasiun televisi swasta Jakarta bersiaran nasional seringkali jatuh pada tujuan pariwisata. Tayangan budaya mereka kebanyakan berbentuk feature tentang budaya masyarakat tertentu atau cerita perjalanan yang berganti tiap episode.

Acara Pangkur Jenggleng tayang di TVRI Jogja setiap hari Senin pukul 18.00 - 19.00. Cerita Pangkur Jenggleng adalah cerita di sebuah padepokan yang bernama Padepokan Ayom Ayem. Di sana ada orang-orang yang berperan layaknya kehidupan sehari-hari. Di sana pula persoalan-persoalan sehari-hari dibahas sesuai dengan tema yang diangkat. Dalam padepokan tersebut terdapat seorang yang dituakan yang nantinya memberi nasihat kepada orang-orang yang ada di sana.

Tayangan ini memiliki format “dagelan Mataram”, yaitu berupa lawakan yang diselingi dengan musik. Tema lawakan yang diangkat dalam acara ini menyangkut masalah kehidupan seharihari atau tentang isu yang sedang populer, misalnya tema "kurban" saat mendekati Hari Raya Idul Adha, "kwalon" untuk membahas tentang saudara tiri, "njago" untuk membahas tentang banyaknya orang yang berniat mencalonkan diri 
menjadi anggota legislatif maupun eksekutif, dan lain sebagainya.

Selain menghibur, acara ini juga berusaha memberikan refleksi bagi penonton atas kehidupan sehari-hari. Format dagelan dipilih karena pesan dianggap bisa lebih mudah diterima oleh penonton. Dengan format tersebut, acara Pangkur Jenggleng menjadi acara budaya yang paling banyak disukai oleh penonton di wilayah Yogyakarta dan sekitarnya.

Nama Pangkur Jenggleng diambil dari nama salah satu tembang macapat, yaitu Pangkur. Adapun Pangkur Jenggleng adalah cara menyajikan tembang Pangkur yang bisa diselingi dengan lawakan di tengah-tengah lagu. Oleh karena itu, format acara ini pun sesuai dengan namanya. Tembang macapat atau lagu yang mengiringi acara bisa dihentikan sewaktu-waktu dengan guyonan yang seringkali muncul secara spontan dari para pengisi acara. Kemudian lagu dilanjutkan lagi setelah semua selesai tertawa.

\section{Lawakan Pangkur Jenggleng} selalu diiringi dengan musik. Pada setiap episode akan ada penyanyi yang menyanyikan lagu-lagu campur sari, keroncong, lagu-lagu Jawa, atau tembang macapat sesuai dengan kebutuhan dengan diiringi gamelan. Selain menyanyi, penyanyi dalam acara ini juga harus bisa berakting dan melawak karena format Pangkur Jenggleng sebagaimana yang dijelaskan di atas mewajibkan mereka untuk turut serta berakting dan melawak.

Acara ini melibatkan artis-artis lokal, mulai penyanyi, pelawak, pengrawit, dan bintang tamu lainnya. Artis-artis tersebut berasal dari Yogyakarta maupun kota-kota di wilayah sekitar (Klaten, Sragen, Wonogiri, Solo, Kebumen, dan lain-lain). Beberapa nama populer yang pernah menjadi bintang tamu di acara ini adalah Yati Pesek, Soimah Pancawati, serta Ki Ngabdul (Alm.) yang menjadi tokoh utama.

\section{Kebutuhan Publik akan Program Budaya}

Tayangan televisi swasta Jakarta yang bersiaran nasional seringkali monoton dan membuat penonton membutuhkan tayangan alternatif. Tayangan budaya merupakan salah satu alternatif tayangan yang mereka sukai. Hal ini terbukti dari hasil penelitian kami yang menunjukkan bahwa tayangan budaya lokal disukai oleh responden. Tayangan budaya yang disiarkan oleh berbagai stasiun televisi lokal mendapat tempat tersendiri bagi khalayak.

Pada tayangan TVRI Jogja, acara Pangkur Jenggleng menjadi acara yang paling banyak disebut sebagai acara favorit. Acara tersebut dipilih oleh mayoritas responden yang menonton TVRI, yaitu sebanyak 63,89\%. Sementara acara-acara TVRI Jogja lainnya dipilih oleh masing-masing kurang dari 10\%. 
Grafik 2 berikut ini menunjukkan data jumlah responden yang menonton acaraacara di TVRI Jogja.

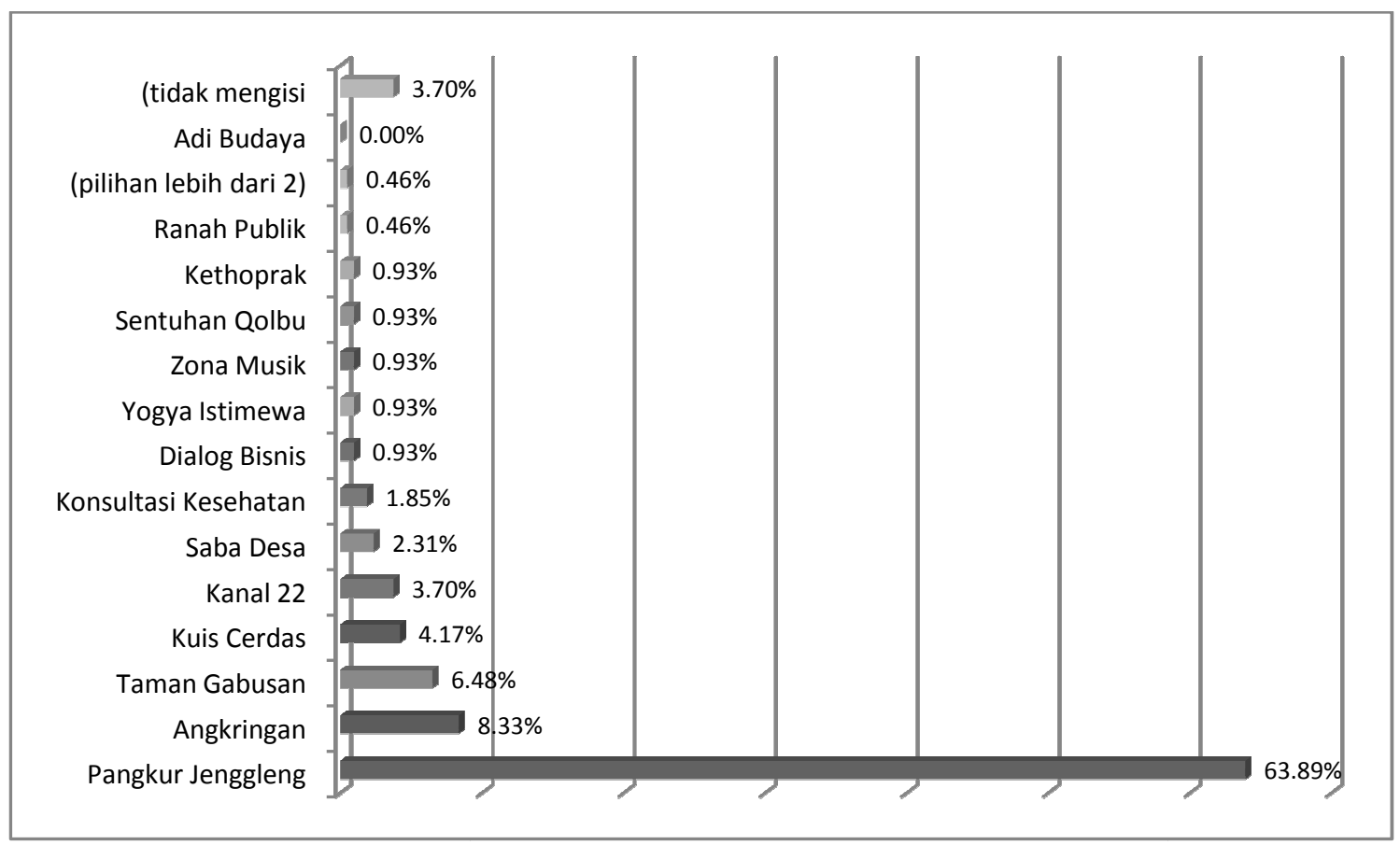

Grafik 2. Program Siaran TVRI yang Ditonton Responden

Acara Pangkur Jenggleng memang disukai oleh masyarakat di wilayah Yogyakarta dan sekitarnya. Selain dari penelitian di atas, pada bulan Juli AC Nielsen pun mencatat Pangkur Jenggleng memiliki rating hingga 6,2\%. Selain itu, pada setiap proses pengambilan gambar pun selalu ditunggu-tunggu oleh masyarakat. Menurut Heruwati, produser acara ini, penonton harus rela menunggu panggilan hingga 7 bulan untuk bisa menyaksikan acara Pangkur Jenggleng di studio.

Tingginya animo masyarakat terhadap acara Pangkur Jenggleng mestinya bisa menjadi indikasi kebutuhan publik akan tayangan budaya. Tayangan
Pangkur Jenggleng dianggap bisa memberikan hiburan sekaligus memberikan pendidikan serta melestarikan kebudayaan. Acara ini mampu memberikan hiburan yang segar di tengah acara televisi lain yang dianggap monoton. Selain itu, acara ini juga dianggap mampu memberikan refleksi atas pengalaman kehidupan sehari-hari dan mencerminkan kebudayaan mereka.

Sayangnya, tayangan semacam Pangkur Jenggleng belum bisa diproduksi oleh stasiun televisi, baik yang bersiaran nasional maupun lokal. Nyatanya, Pangkur Jenggleng menguasai mayoritas perhatian penonton. Belum ada acara lain yang bisa sesukses Pangkur 
Jenggleng dalam merebut perhatian masyarakat, setidaknya oleh stasiun televisi yang tayang di wilayah Yogyakarta.

Keadaan tersebut menjadi catatan tersendiri bagi para pegiat media. Beberapa tantangan yang dihadapi oleh media sehingga belum bisa menyajikan tayangan-tayangan yang bisa memenuhi kebutuhan dan keinginan publik antara lain:

1. Lemahnya regulasi media yang tidak memberikan kesempatan kepada televisi lokal maupun tayangan lokal untuk hadir di tengah-tengah penonton. Seperti yang selama ini terjadi, syarat televisi swasta Jakarta yang bersiaran nasional untuk memberikan porsi yang cukup untuk tayangan lokal tidak pernah diindahkan. Dengan keadaan demikian, tak akan ada upaya dari pihak stasun televisi untuk menggarap program lokal secara serius.

2. Jam siar yang kurang. Hal ini terjadi terutama pada tv publik. TVRI lokal hanya memiliki jam siar 4 jam, yaitu mulai pukul 15.00 - 17.00. Dengan waktu yang sesingkat itu, kiranya perlu tambahan waktu bagi stasiun lokal sehingga bisa memberikan pelayanan yang lebih banyak kepada publik.

3. Kualitas televisi lokal yang masih kurang.
Dengan berbagai keterbatasan, baik finansial maupun sumber daya manusia, membuat acara yang prima seperti Pangkur Jenggleng dalam jumlah banyak akan terasa sangat sulit. (4) Sentralisasi sistem penyiaran yang membuat akumulasi kapital berada di tangan televisi Jakarta bersiaran nasional. Sistem penyiaran yang tersentralisasi sangat merugikan televisi lokal karena pemasukan dari iklan dikuasai oleh televisi Jakarta bersiaran nasional. Mereka menguasai hampir $67 \%$ belanja iklan nasional yang diperkirakan mencapai lebih dari Rp9o triliun. Sisanya dibagi untuk televisi lokal di seluruh Indonesia (data AC Nielsen kwartal 2 tahun 2013, dalam Sudarmawan, 2013). Keadaan yang demikian berakibat pada keterbatasan yang harus dihadapi oleh televisi lokal untuk memproduksi siaran yang bagus dan berorientasi pada kebutuhan publik, terutama acara budaya.

\section{Penutup}

Tayangan budaya, terutama yang bersifat lokal, ternyata sangat dibutuhkan oleh publik. Salah satu tayangan yang menunjukkan betapa publik menginginkan tayangan yang menarik dan mampu mengangkat budaya lokal adalah Pangkur Jenggleng. Akan tetapi, acara budaya seperti Pangkur Jenggleng tak diproduksi oleh stasiun televisi lain. Televisi Jakarta yang bersiaran nasional tak punya tempat untuk acara-acara yang 
bersifat lokal. Acara seperti ini juga dianggap tidak mampu mendatangkan keuntungan finansial yang besar. Sementara televisi lokal seringkali kesulitan membuat acara yang menarik dan berkualitas karena keterbatasan finansial dan sumber daya manusia.

Kelangkaan tayangan budaya, terutama yang bersifat lokal, mestinya harus dipecahkan oleh sistem media penyiaran mengingat urgensinya dan betapa kuatnya kebutuhan publik akan tayangan tersebut. Upaya untuk mendukung tayangan yang berisi budaya lokal harus segera dilakukan. Sentralisasi penyiaran yang selama ini berlaku harus segera dihentikan. Televisi lokal harus didukung, terutama oleh pemerintah, sehingga televisi lokal bisa lebih banyak memproduksi tayangan-tayangan yang berkualitas dan menarik. Industri media penyiaran harus terdesentralisasi sehingga belanja iklan bisa dipecah ke lebih banyak pihak, tidak hanya dikuasai oleh televisi Jakarta yang bersiaran nasional.

Dukungan terhadap lembaga penyiaran publik juga menjadi kebutuhan yang mendesak. Bagaimanapun, lembaga penyiaran publik berkewajiban untuk membuat program budaya sebagaimana yang dibutuhkan oleh publik. Dengan sistem yang memperkuat media penyiaran lokal dan lembaga penyiaran publik, tayangan budaya yang menarik dan bisa mengangkat kebudayaan lokal serta dapat menjawab kebutuhan publik bisa lebih banyak diproduksi. Jika demikian, publik pun akan memiliki rujukan yang lebih banyak atas program budaya untuk mengembangkan diri dan kebudayaan lokal bisa mendapat tempat untuk terus berkembang.

\section{Daftar Pustaka}

Gazali, Effendi. 2002. Penyiaran Alternatif, tapi Mutlak: Sebuah Acuan tentang Penyiaran Publik dan Komunitas. Jakarta: Jurusan Ilmu Komunikasi FISIP Universitas Indonesia

Higgins, Michael. 2008. Media and Their Publics. New York: McGraw HillOpen University Press

Ibrahim, Idi Subandy. 2011. Kritik Budaya Komunikasi: Budaya, Media, dan Gaya Hidup dalam Proses Demokratisasi di Indonesia. Yogyakarta: Jalasutra

Kellner, Douglas. 2010. Budaya Media: Cutural Studies, Identitas, dan Politik: Antara Modern dan Posmodern. Yogyakarta: Jalasutra McChesney, Robert W. 200o. Rich Media, Poor Democracy: Communication Politics in Dubious Times. New York: The New Press

McManus, John H. 1994. Market-Driven Journalism: Let the Citizen Beware. Thousand Oaks, London, New Delhi: Sage Publications 
McNair, Brian. 2003. An Introduction to Political Communication. third edtition, London and New York: Routledge

Rianto, Puji, dkk. 2013. Laporan Riset Penonton dan Program Siaran TVRI di Wilayah Yogyakarta. Yogyakarta: Inspect dan Pulitbang LPP TVRI.

Sendjaja, Sasa Djuarsa. 2006. "Badan Hukum TVRI dan RRI sebagai Lembaga Penyiaran Publik", Jurnal Bisnis dan Birokrasi No. 02/Vol. XIV/Mei/2006
Sudarmawan, Wahyu. 2013. Manajemen Televisi Lokal: Strategi Bisnis Berjaringan, Suatu Pilihan. Artikel disampaikan pada Workshop Penelitian Kepemilikan Media, Isi Siaran, dan Regulator Penyiaran: Advokasi Kebijakan untuk Demokratisasi Penyiaran di Indonesia. Agustus 2013. 